1992. Hunter-gatherers of the Levantine Epipaleolithic: the socioecological origins of sedentism, Journal of Mediterranean Archaeology 5: 165-201.

MARKS, A.E. 1976a. Site D5: A Geometric Kebaran 'A' occupation in the Nahal Zin, in Marks (1976b): 293316.

(Ed.). 1976b. Prehistory and paleoenvironments in the Central Negev, Israel I. Dallas (TX): Southern Methodist University Press.

(Ed.). 1977. Prehistory and paleoenvironments in the Central Negev, Israel II. Dallas (TX): Southern Methodist University Press.

1983. The Middle to Upper Paleolithic transition in the Levant, Advances in World Archaeology 2: 51-98.

1988. The curation of stone tools during the Upper Pleistocene, in H.L. Dibble \& A. Montet-White (ed.), Upper Pleistocene Prehistory of Western Asia: 27585. Philadelphia (PA): University Museum, University of Pennsylvania.

1989. Early Mousterian settlement patterns in the
Avdat/Aqev area, in M. Otte (ed.), L'homme de Néandertal 6: La subsistance: 115-26. Liège: Université de Liège. ERAUL 33.

MARKS, A.E. \& D.A. FRIEDEL. 1977. Prehistoric settlement patterns in the Avdat/Aqev area, in Marks (1977): 13158.

MARKS, A.E. \& A.H. SimMONS. 1977. The Negev Kebaran of the Har Harif, in Marks (1977): 233-70.

Movious, $\mathrm{H}$, et al. 1968. The analysis of certain major classes of Upper Paleolithic tools. Cambridge (MA): Peabody Museum Press. American School of Prehistoric Research Bulletin 26.

MUNDAY, F. 1976. Intersite variability in the Mousterian occupation of the Avdat/Aqev area, in Marks (1976b): 113-40.

NEELEY, M.P. \& C.M. BARTON. 1994. A new approach to interpreting late Pleistocene microlith industries in southwest Asia, Antiquity 68: 275-88.

SIMMONS, A.H. 1977. The Geometric Kebaran 'A' camp site of D101C, in Marks (1977): 119-29.

\title{
Technology or typology?: a response to Neeley \& Barton
}

\section{ROBERT FELLNER *}

\section{Two further points in Neeley \& Barton's 1994 paper are explored.}

In a paper published in the June 1994 issue of ANTIQUTTY, Neeley \& Barton develop an argument purporting to demonstrate that differences in microlith morphology observed in Epipalaeolithic assemblages from the Near East are the product of technological rather than stylistic variation. If true, their hypothesis would undermine the validity of much of the research in this field carried out during the last 30 years.

Neeley \& Barton's paper contains two main arguments:

the microburin technique - a method for sectioning bladelets by placing and deepening a notch until the bladelet snaps (see Tixier 1963: 39-42; Fellner 1995: 53-7) - is not specific to any Epipalaeolithic industry in the Near East, but was used universally;

variation in microlith forms - used by many researchers as fossiles directeurs to identify archaeological cultures - is not due to changes in style but the product of resharpening blunted or broken microliths. Both arguments appear highly questionable.

\section{The microburin technique}

Neeley \& Barton accept the current evidence that the number of microburins (the waste product of the microburin technique) varies strongly among Epipalaeolithic assemblages; those assigned to Kebaran or Geometric Kebaran A industries contain markedly fewer microburins than those assigned to Mushabian or Ramonian industries. In the traditional view, this variation is additional evidence for the existence of discrete archaeological cultures identified by microlith morphology. Neeley \& Barton argue that it is purely a reflection of raw material constraints. They note that the trapeze/rectangles considered typical of Geometric Kebaran A assemblages are slightly shorter (mean 22 mm, SD 4; Goring-Morris 1987: 1278) than the microlithic points common to Mushabian and Ramonian sites (24 mm, SD 4.5; and $26 \mathrm{~mm}$, SD 3; Goring-Morris 1987: 187-8 and 240-41 respectively), while the trend in bladelet blank length is opposite, witn an average of $36 \mathrm{~mm}$ for Geometric Kebaran A and $31 \mathrm{~mm}$ for Mushabian assemblages (based on

* Route de Fontenais 27, 2900 Porrentruy, Switzerland.

Received 8 December 1994, accepted 4 March 1995.

ANTIQUTTY 69 (1995): 381-3 
a rather small sample; Henry 1989). Neeley \& Barton observe that the average Mushabian microlith accounts, in length, for $80 \%$ of the average blank size, while Geometric Kebaran A trapeze/rectangles account, on average, for only $61 \%$ of the blank. This they take to suggest that 'two (or more) microliths were produced from many Geometric Kebaran bladelets, rather than a microlith and a discarded microburin' ( $p$. 280 ); they argue that the rarity of microburins in Geometric Kebaran A assemblages does not indicate the absence of that technique: it was simply used without creating waste products.

Neeley \& Barton's argument is open to a considerable number of objections: the quality of the numerical evidence on blank size; an analysis based on recognized archaeological cultures while at the same time questioning their reality; raw-material scarcity as an explanatory mechanism in a context where this seems rare; ignoring the traces left by the microburin technique on microliths produced in this way; etc. (see Kaufman, this volume). I will only discuss the most obvious. Trapeze/rectangles, considered typical of the Geometric Kebaran A industry, are microliths with truncations on both ends. The truncations indicate that both the tip and the platform end of the bladelet blank had to be removed to produce this tool type, reducing the workable portion of blank length from an average of $36 \mathrm{~mm}$ for the complete object to, at most, $32 \mathrm{~mm}$. How more than one of the $22 \mathrm{~mm}$ long (on average) trapeze/rectangles should frequently be produced from one blank seems thus a mystery. To put it differently: $61 \%$ is more than half, and certainly more than a third. This being so, the rarity of microburins in Geometric Kebaran A assemblages does indicate that the technique - common in Mushabian, Ramonian and Desert Natufian sites - was not or only rarely used by those producing trapeze/rectangles.

\section{Microlith form and re-sharpening}

Neeley \& Barton's second argument is more consistent, though no less questionable. True, it is not impossible that changes in microlith forms could be brought about by re-sharpening or reworking these tools. Trapezes could become lunates or triangles, arch-backed bladelets might be transformed into rectangles, etc. But this mechanism cannot explain the Epipalaeolithic data from the Near East. Assemblages have been traditionally assigned to various archaeological cultures because they are usually dominated by one particular (or a suite of 'related') type(s) of microliths. Microliths from Geometric Kebaran A sites, for instance, consist (by definition) to more than $50 \%$ of trapeze/rectangles (Bar-Yosef 1970: 172), while other forms typical of different archaeological cultures, such as ramon points or helwan lunates, are either completely absent or intrusive from overlying, later deposits (Valla 1989). In the most standardized of Epipalaeolithic assemblages from Palestine - a group of Early Ramonian sites found in the Negev Desert - one type accounts for an average of $85 \%$ of all identifiable microliths (SD 10, $n=7$; Fellner 1995: 40), while trapeze/rectangles are completely absent. If Neeley \& Barton's argument was correct, we would expect to find that all assemblages contain a more or less even mix of all microlith types, as these would simply represent various stages in a manufacturing and re-working process, rather than definite, designed end-products. The standardization common among microlithic assemblages from the Near Eastern Epipalaeolithic runs counter to Neeley \& Barton's argument.

There are other objections to the 're-sharpening argument'. Microliths are small and fragile. Extensive reworking would prove rather difficult. Furthermore, the only apparent advantage of microliths (in a region where raw material is usually abundant) lies in their modular nature; each of these small tools, hafted in arrays as part of projectiles or knives (Fellner 1995: 60) can be easily replaced (after damage or loss) by another standardized element of similar size and shape. Re-sharpening or reworking of microliths would actually negate this advantage. Finally, the definition of archaeological cultures on the basis of microlith morphology is strengthened by the observation of consistent stratigraphic relationships (Natufian sites are always found above Geometric Kebaran or Kebaran assemblages in a stratified context), geographical distribution (e.g. Mushabian sites are not found outside southern Palestine), and the covariation of microlith form and other ' $\mathrm{di}$ agnostic' elements, such as technology (e.g. microburin technique) or the presence of particular structures (Fellner 1995: 87-91).

Neeley \& Barton's arguments are flawed, and we can conclude that 'discrete, predetermined types' of microliths explain the Near Eastern 
Epipalaeolithic evidence better than 'a technological continuum of microlith manufacture, use and discard' (p. 277). The traditionally recognized archaeological cultures do have some basis in fact; whether they reflect the existence of underlying ethnic units, and to what extent

\section{References}

BAR-YOSEF, O. 1970. The Epipalaeolithic cultures of Palestine. Unpublished Ph.D thesis, Hebrew University, Jerusalem.

FELLNER, R. 1995. Cultural change and the Epipalaeolithic of Palestine. Oxford: British Archaeological Reports. International series 599 .

Goring-MORRIS, A.N. 1987. At the edge: terminal Pleistocene hunter-gatherers in the Negev and Sinai. Oxford: British Archaeological Reports. BAR International series 361 .

HENRY, D.O. 1989. From foraging to farming: the levant at they may do so, is however a different and much more complicated question. I would refer those interested in this subject to my Cultural change and the Epipalaeolithic of Palestine, recently published in the British Archaeological Reports International Series, Oxford.

the end of the Ice Age. Philadelphia (PA): University of Pennsylvania Press.

TIXIER, J. 1963. Typologie de l'Epipaléolithique du Mahgreb. Paris: Arts et Métiers Graphiques. Mémoires du CRAPE, Algiers 2.

Valla, F. 1989. A propos du Kébarien Géométrique de la terasse d'Hayonim (fouilles D. Henry, 1974-1975), in O. Bar-Yosef \& B. Vandermeersch (ed.), Investigations in South Levantine prehistory/Préhistoire du SudLevant: 255-73. Oxford: British Archaeologica] Reports. International Series 497.

\section{Macedonia then and now: a comment on Brown}

\section{GeORge Phillipov*}

Brown's recent article (ANTIQUITY 68 (1994): 784-96) characterizes the bias held by some contemporary anthropologists when dealing with the 'Macedonian Question'. The failure of objectivity leads Brown to misrepresent crucial events and overlook major historic themes where the Bulgarian nation is concerned. Through this subjective revisionism Brown sanctions untruths, whereby unequivocally Bulgarian early medieval history - like King Samuil and the Ohrid Archiepiscopate - is promoted as 'distinctively Macedonian'. This highlights Brown's prejudice with respect to the factual history of the region, which incidentally from the 9th to 19th centuries was not even called 'Macedonia', but 'Lower Land' a part of the Bulgarian nation.

There are in fact numerous texts written by westerners who visited Macedonia for extended periods at the turn of the century - Protestant missionaries, adventurers, historians, etc. - and just like Brailsford they all report that the people had a Bulgarian self-awareness. Yet this does not deter Brown from re-labelling them as 'Slavs' and their language as 'Macedonian', the codification of which in 1944 must be seen as a political, not a linguistic process, decreed after a committee met for a mere six days. Perhaps this explains why a main policy of the VRMO-DPMNE political party is revision of the language based on its pre-1944 status.

While Brown mentions Goce Delchev, he neglects to inform readers that Delchev and his fellow revolutionaries self-identified as Bulgarians - in their speeches, letters and memoirs. Delchev's 'bones' were given to Skopje by the Bulgarian Communists during an era of national nihilism, in which Pirin Bulgarians were forced to become 'Macedonian' nationals to expedite formation of a Balkan Federation thousands of Bulgarians chose prison instead. Chupovski, however, was truly a person who self-identified as a 'Macedonian', but he also collaborated with the Ottoman government, and spent almost all his life abroad in Russia, since Delchev's organization had him 'marked'

* 40 Nedford Crescent, Fulham Gardens SA 5024, Australia.

Received 28 January 1995, accepted 1 March 1995.

ANTIQUITY 69 (1995): 383-4 